\title{
The valuation of environmental services in the price formation of native rubber in
}

\author{
Acre \\ A avaliação dos serviços ambientais na formação de preços da borracha nativa no Acre \\ La valoración de los servicios ambientales en la formación de precios del caucho nativo en Acre
}

\author{
Raimundo Cláudio Gomes Maciel \\ ORCID: https://orcid.org/0000-0001-8979-4895 \\ Federal University of Acre, Brazil \\ E-mail: rcgmaciel@bol.com.br \\ César Leandro de Christo Hundertmarck \\ ORCID: https://orcid.org/0000-0002-4510-6015 \\ Federal University of Acre, Brazil \\ E-mail: adm.cesarlch@gmail.com \\ José Roberto Kassai \\ ORCID: https://orcid.org/0000-0003-4879-7197 \\ University of São Paulo, Brazil \\ E-mail: jrkassai@usp.br \\ João Alfredo de Carvalho Mangabeira \\ ORCID: https://orcid.org/0000-0001-9417-4455 \\ Brazilian Agricultural Research Corporation, Brazil \\ E-mail: joao.mangabeira@embrapa.br \\ Pedro Gilberto Cavalcante Filho \\ ORCID: https://orcid.org/0000-0003-1776-0295 \\ University of Campinas, Brazil \\ E-mail: pedro.gilberto@ hotmail.com \\ Alisson Mello Munaretti \\ ORCID: https://orcid.org/0000-0001-8979-4895 \\ Federal University of Acre, Brazil \\ E-mail: alissonmm.florestal@gmail.com
}

\begin{abstract}
The disarticulation of traditional extractionism in the 1960 s led to serious socio-economic and environmental problems in the Amazon. The Extractive Reserves (RESEX) arose as a sustainable development alternative for the region. However, the unique challenges in extractive activities - such as native rubber - continue to result in difficulties with economic viability since the market fails to capture the environmental attributes of the forests. These failures may impact the maintenance of eco-systemic services. The payments for environmental services, such as the environmental certification, arise as a way to compensate those who carry out environmental services. The general aim of this study is to evaluate the environmental valuation in the price formation of the rubber productive chain in the state of Acre. We work with the methodology of price formation through trade margin indicators (Markup) and Effective Appropriation according to the structure of the market circuits of the rubber productive chain in the region. Our results indicate that the extractivists of the Chico Mendes RESEX obtained, in the period of 2018/2019, a level of remuneration for their environmental services which may lead to economic viability in rubber production. However, from the standpoint of maintenance of environmental services - as well as the maintenance of the families of the extractivists - that remuneration is still not enough for an effective environmental valuation.
\end{abstract}

Keywords: Environmental valuation; Price formation; Native rubber; Productive chain; Chico Mendes RESEX.

\section{Resumo}

A desarticulação do extrativismo tradicional na década de 1960 gerou sérios problemas socioeconômicos e ambientais na Amazônia. As Reservas Extrativistas (RESEX) surgiram como uma alternativa de desenvolvimento sustentável para a região. No entanto, os desafios singulares das atividades extrativas - como a borracha nativa - continuam a resultar em dificuldades de viabilidade econômica, uma vez que o mercado deixa de captar os atributos ambientais das florestas. Essas falhas podem impactar a manutenção dos serviços ecossistêmicos. Os pagamentos por serviços ambientais, como a certificação ambiental, surgem como uma forma de compensar quem realiza os serviços ambientais. O objetivo geral deste estudo é avaliar a valoração ambiental na formação dos preços da cadeia produtiva da borracha no estado do Acre. Trabalhamos com a metodologia de formação de preços por meio de indicadores de margem comercial e Apropriação Efetiva de acordo com a estrutura dos circuitos de mercado da cadeia produtiva da borracha na região. Nossos resultados indicam que os extrativistas da Resex Chico Mendes obtiveram, no período de 
2018/2019, um nível de remuneração por seus serviços ambientais que pode levar à viabilidade econômica na produção de borracha. Porém, do ponto de vista da manutenção dos serviços ambientais - bem como da manutenção das famílias dos extrativistas - essa remuneração ainda não é suficiente para uma efetiva valoração ambiental.

Palavras-chave: Avaliação ambiental; Formação de preços; Borracha nativa; Cadeia produtiva; RESEX Chico Mendes.

\section{Resumen}

La desarticulación del extractivismo tradicional en la década de 1960 provocó graves problemas socioeconómicos y ambientales en la Amazonía. Las Reservas Extractivas (RESEX) surgieron como una alternativa de desarrollo sustentable para la región. Sin embargo, los desafíos únicos en las actividades extractivas, como el caucho nativo, continúan generando dificultades con la viabilidad económica, ya que el mercado no logra capturar los atributos ambientales de los bosques. Estas fallas pueden afectar el mantenimiento de los servicios ecosistémicos. Los pagos por servicios ambientales, como la certificación ambiental, surgen como una forma de compensar a quienes realizan servicios ambientales. El objetivo general de este estudio es evaluar la valoración ambiental en la formación de precios de la cadena productiva del caucho en el estado de Acre. Trabajamos con la metodología de formación de precios a través de indicadores de margen comercial (Markup) y Apropiación Efectiva de acuerdo a la estructura de los circuitos de mercado de la cadena productiva del caucho en la región. Nuestros resultados indican que los extractivistas de la RESEX Chico Mendes obtuvieron, en el período 2018/2019, un nivel de remuneración por sus servicios ambientales que puede conducir a la viabilidad económica en la producción de caucho. Sin embargo, desde el punto de vista del mantenimiento de los servicios ambientales - así como del mantenimiento de las familias de los extractivistas - esa remuneración aún no es suficiente para una valoración ambiental efectiva.

Palabras clave: Valoración ambiental; Formación de precios; Caucho nativo; Cadena productiva; Chico Mendes RESEX.

\section{Introduction}

The disarticulation process of traditional extractivism in the Amazon - in particular in Acre - stemming from "modern" activities such as agropastoralism has led to serious socioeconomic and environmental problems, such as the struggle for ownership of the land and the rampant deforestation in the region.

Therefore, the social movement of the tappers became an important ally to the global environmental movement in the search for a new, sustainable mode of development for the Amazon region.

In this process, the Extractive Reserves (RESEX) have been implemented as a way to guarantee not only the ownership of land to the extractivists, but also social justice, ecological prudence, and economic viability.

This latter dimension, unlike the others, is still a barrier to the development of the RESEXes because the products of vegetal extractivism, such as native rubber, face competition in the traditional market from producers of synthetic and cultivation rubber, which leads to a lowering of prices that is characteristic of the price formation of commodities.

We highlight that conventional markets fail to capture, in prices, the attributes of sustainable products such as those that come from conservation zones like the RESEXes. The environmental certification is a mechanism that may be utilized in the valuation of the attributes of socio-bio-diversity products and help the extractivists of the RESEX reach economic viability.

The general goal of this work is to evaluate the environmental valuation in the price formation of the rubber productive chain in the state of Acre. Specifically, we aim to: 1. Analyze the structure and the operation of the market circuits of the rubber traded in the state of Acre; 2. Analyze the flow of supply and demand of that productive chain, highlighting the payment for socio-environmental services in the price formation.

We work with the following research question: is the payment for socio-environmental services added to the prices of the native rubber from the Chico Mendes RESEX enough to grant economic viability to this kind of production?

Our research hypothesis is: the prices that RESEX producers receive for their rubber, including the parcel added due to socio-environmental services, may, together with necessary adaptations to the productors' handling and organization, enable them to reach economic viability. However, these prices are not enough to viabilize the entire productive unit given that the income earned is not enough to satisfy the local families' necessary living expenses. 
Therefore, the maintenance of the forests and of the environmental services stemming from that ecosystem may be compromised, for they depend directly on the continuity and maintenance of extractivist families in the region; those families, in turn, face many difficulties in increasing the revenue of traditional production, leading them, in some cases, to make use of unsustainable (environmentally speaking) productive activities, such as cattle farming.

\section{Sustainable Development and the Extractive Reserves in the Amazon}

After the implementation of the military regime, post-1960, Brazil went through intense transformations as part of a development process that sought to reach the dream of "Brasil Potência" (Brazil as a world power). One of these transformations happened in rural Brazil with the so-called process of conservative modernization. A particular face of that process was the occupation of agricultural frontiers by great enterprises, strongly sponsored by the federal government (Wanderley, 2014).

That process led to the recent transformations in the Amazon, with the disarticulation of traditional extractivism in favor of "modern" activities such as agropastoralism; this in turn led to serious socio-economic and environmental problems, such as the disappearance of traditional populations, the struggle for land ownership, and rampant deforestation in the region (Maciel, 2003, 2007).

The struggle for the ownership of land began in the 1970s with a resistance movement from the tappers, who had their lands sold, and who forced various stalemates ${ }^{1}$ with the lands' new owners in defense of the maintenance of the rubber extraction zones and of the forests that guaranteed their livelihood.

Furthermore, in the decade of 1980, according to Maciel (2003), the environmentalist movement is consolidated both in national and international terms, effectively initiated in the previous decade, [and the movement] became the main ally of the tappers' movement in their struggle for land and defense of the Amazonic forests. ${ }^{2}$

A mark of that period is the publication of the document titled "Nosso Futuro Comum" ("Our Collective Future") in 1987, also known as the Brundtland Report, written by the World Commission on Environment and Development (WCED, CMMAD in Portuguese). The report established the definition of sustainable development: "it is that which fulfills the needs of the present without compromising the possibility of future generations fulfilling their own needs" (CMMAD, 1991, p. 46). This aimed to address the fact that the development mode of the world was causing immense environmental damage, endangering the future survival of the human race.

According to Maciel (2007), the implementation of public policies that aim to alter the current development pattern of the Amazon region is paramount in order to reach effective sustainable development, the main dimensions of which are: ecologic prudence, social justice, and economic efficiency. ${ }^{3}$

Among the environmental policies that sought to push back against the post-1960 transformations of Amazonian developmentalism, we highlight the creation of the Conservation Units (UC), initially based on strategic conservation zones for indirect-use biodiversity (Hall, 2000; Maciel, Cavalcanti, de Souza, de Oliveira, \& Cavalcante Filho, 2018; Silva, Silva, \& Yamada, 2019).

According to Young and Medeiros (2018, p. 14), every country has the goal to create and maintain protected areas,

\footnotetext{
1 According to Almeida (2004, p. 50): "Empates" (lit. 'draws', here translated as 'stalemates') are collective actions aiming to stop the clearance of forests, which was preceded by the expulsion of tappers and appropriation of their lands. The first stalemates of this kind happened in the city of Brasiléia with Wilson Pinheiro, then to be continued by Chico Mendes. Both were assassinated under orders from landowners.

${ }^{2}$ About that alliance, see also Drummond and De Souza (2016).

${ }^{3}$ According to Butzke (2001) cited by Tavares et al. (2020, p. 14) "Presently, the human race is reviewing the concept of development, giving the criteria of ecological balance and social justice the same emphasis that is given to economic viability (...) [these are] the three pillars of sustainable development.”
} 
seeking to fulfill the three fundamental aims of the Convention on Biological Diversity (CBD): "the conservation of biological diversity, the sustainable use of its components, and the fair and equitable distribution of the benefits derived from the use of its genetic resources.

In the face of the growing worldwide environmental movement along with the tappers movement, the indirect use UCs stand out, particularly the Extractive Reserves (RESEX). According to Maciel et al. (2018, p. 403), "the RESEX were created with an innovative proposal, keeping in mind their land policy, which consists in the role of resolving land conflicts, and an environmental policy, observing the precepts of sustainability towards the preservation of natural resources."

According to Barbosa de Almeida et al. (2018), “ 'Extractive Reserves' is a concept created by tappers and not by environmentalists, with the goal of ensuring the land rights and well-being of extractive families - with the preservation of the natural resources upon which that well-being is based."

It's important to note that the extractivists themselves had, since the inception and implementation of the RESEX, conviction of their economic viability once the organization of the tappers would increase the productivity of non-timber forest products via the introduction of new technologies (STR/CNS/CUT, 1989 cited by Barbosa de Almeida et al., 2018).

Maciel (2003) already evidenced that the technological deficiency identified in extractive productive activities still hasn't been resolved. The innovation process depends not only on the organization of the tappers, but also on effective public policies to implement and maintain innovations in products and processes. This is true even for innovations already available, such as was the case with the Islands of High Productivity, which became a public policy in the state of Acre, in 1999, only to be abandoned four years later.

To Maciel et al. (2019), economic efficiency, one of the three pillars of sustainable development, is still a big challenge for the RESEX, especially for the generation of jobs and income, because there's still a lack of effective public policies to foster the development of economic instruments in the region.

Maciel (2007) affirms that an alternative for the economic viability of extractivist products is precisely the environmental economic valuation mediated by the mechanism of environmental certification: for indeed, the economic nonviability of the extractivist products of the Chico Mendes RESEX can be linked to the low prices of the RESEX's main products - rubber and Brazil nuts - and that is because conventional markets fail to capture, in their pricing, the environmental attributes of these products, notedly the maintenance of the forests' ecosystem services ${ }^{4}$.

Thus, the environmental certification can capture, adjusting the market values, the environmental attributes of the extractivist products from the RESEXes, granting them economic viability and taking advantage of the price formation of commodities, such as natural rubber.

To valuate the ecosystem services of the forests is precisely to valuate the RESEX, and understanding that relationship is essential in order to visualize the effective role of the environmental certification in the economic efficiency of extractivist products. This will be discussed in the following section.

\section{Ecosystem services and Environmental Economic Valuation}

According to Costanza et al. (2017, p. 3), “ 'ecosystem services' (SE) are the ecological characteristic, functions, or processes which directly or indirectly contribute to human well-being; that is, the benefits that people derive from the functioning of the ecosystems."

The importance of the valuation of ecosystemic systems may be seen in the publication of the Millennium Ecosystem Assessment (MILLENNIUM, 2005) by the United Nations, which became a landmark in the discussions of the relationships

${ }^{4}$ According to Tavares et al. (2020, p. 11) "natural resources will generally be impacted in their market value by their scarcity or abundance. While abundant, natural resources are undervalued" - such as is the case in the Amazonian forests. 
between ecosystem services and their impacts on human well-being.

Figure 1 presents these relationships. The colors of the arrows represent the potential for mediation by socioeconomic factors, and the width of the arrows represent the intensity of linkages between ecosystem services and human well-being.

Figure 1. Linkages between ecosystem services and human well-being.

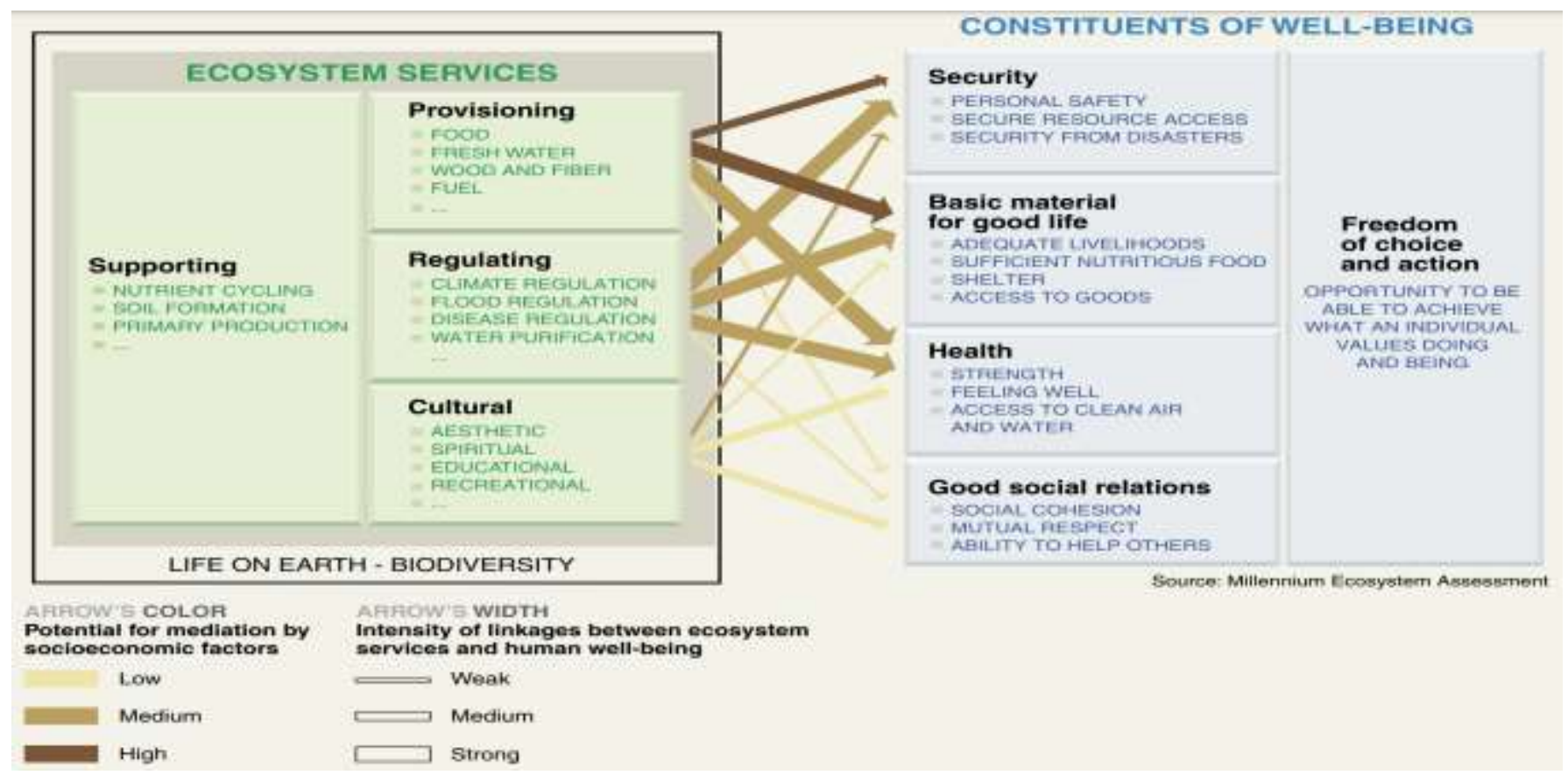

Source: Millennium Ecosystem Assessment (2005).

According to Young and Medeiros (2018, p. 14), protected areas around the world "are fundamental to the maintenance of the integrity of species, populations, and ecosystems, including traditional systems and means of subsistence of human populations.

Barbosa de Almeida et al. (2018) point out that the RESEX play important social and environmental services, such as the conservation of forest cover and biological diversity, keeping in mind the combination of low population density and lowimpact technology.

According to Drummond and De Souza (2016, p. 18), an important aspect of the RESEX is precisely the production of so-called "renewable" goods, that is, goods "that have their stores replenished by natural processes at a time scale compatible with human culture and the connected social processes." This capacity for resilience is fundamental to the very concept of the RESEX, which may guarantee sustainable production.

From an economic standpoint, Young and Medeiros (2018) relate ecosystem services to the concept of positive environmental externalities, which are associated with the creation and maintenance of the UCs, being applicable to both goods (tangible) and services (intangible).

Still according to Young and Medeiros (2018, p. 18), "the concept of 'environmental services' usually refers to human actions taken to protect ecosystem services and which therefore are eligible to receive compensation, monetary or otherwise, for said actions [which include] the creation and maintenance of UCs." 5

Furthermore, even though the majority of Brazilian UCs do not generate their own revenue, they generate value in how they protect a vast range of ecosystem services which directly or indirectly benefit human societies, particularly those

${ }^{5}$ On the broadening of the concept of ecosystem services to environmental services, see also Mamed and Dallabrida (2016). 
situated closer to UCs (Young \& Medeiros, 2018, p. 32).

Costanza et al. (2017, p. 7) affirm that even without any subsequent evaluation, the very process of listing all the services derived from an ecosystem may help to guarantee its recognition in public policies. Furthermore, evaluations are frequently useful because many decisions involve trade-offs between a variety of things which affect human well-being in different ways. In these cases, there really isn't a choice.

According to the principle of Total Economic Value (TEV): "the value of an environmental resource can be obtained by the sum of the goods and ecosystem services provided by it, with or without market values" (Young \& Medeiros, 2018, p. 32). There are various techniques of economic valuation which may be used according to each goal or study project, and which make estimates between the various values-in-use (direct and indirect) of option or existence of the analyzed ecosystems. ${ }^{6}$

According to Maciel (2007), the total economic value of the forest areas of the RESEXes is relevant in order to demonstrate the importance of the sustainable activities of these areas - such as the production of native vegetal rubber - over environmentally unsustainable activities - such as the extentensive cattle farming in the region - when thinking about public policies for the Amazon.

However, we highlight the need to internalize the inherent or non-market benefits to the extractivist communities in the region, who usually keep only the preservation costs. According to Kitamura (1995), even with the global movement for the preservation of the Forest, the utilitarian side, of tangible immediate or future use, predominates with regards to the total economic value of the Amazonian Forest.

Therefore, if one looks only at the estimated cash flows of the ecosystemic functions or systems, one misses the immense environmental benefits - positive externalities - generated by the traditional extractivism practiced in the RESEX. However, in practice those benefits are not translated into effective earnings for the extractivist producers due to the failure of market prices in capturing the aforementioned environmental benefits.

According to Maciel (2007), a mechanism that may capture the cash flows of those positive environmental externalities is the environmental certification, which consists of an added price - stemming from the certification of socioenvironmental efficiency, following the application of a Green Seal - that is considered a premium paid by the consumers who are willing to pay more for socio-economially and environmentally responsible products.

\section{Price Formation of Agricultural Products and the Environmental Certification}

According to Goeschl and Igliori (2006), the institutions responsible for creating public policies face the challenge of overcoming the fundamental contradiction between the static nature of property rights and the economic competition dynamics in the markets in which the RESEXes aim to operate.

Barbosa de Almeida et al. (2018) note that the economic return of extractivist activities floats according to the variations of the national and international markets, which are outside of the control of the forest families.

Furthermore, Drummond and De Souza (2016) explain that the extractivist economy normally sells products in natura or with minimum processing, thus transferring to other regions the added value from the stages of industrial transformation, commercialization, marketing, transport, etc. of the intermediary and final products.

The same authors also explain (p. 19) that the production chain is a sequence of operations that lead to the processing and finalization of goods, uniting various market agents and seeking to ensure its own existence and betterment - "The technologies and the maximization of profit influence the formation of chains."

Of course, ever since the start of the discussion about implementing the RESEXes, the extractivists were aware of the

\footnotetext{
${ }^{6}$ See also Costanza et al. (2017).
} 
need to bring innovations to their activities. Some specific innovations were introduced, especially in the production of native rubber, such as the recent development of the Liquid Smoking Sheet; ${ }^{7}$ However, such innovations were no more than pilot projects for an expanded commercial scale, such as is the case of the demand made by the Veja Shoes company - called Vert in Brazil - which will be discussed in this study.

Drummond and De Souza (2016, p. 19) affirm that

Occasionally, some processing of the goods extracted via low technology does happen locally, but the amount that contributes towards forming the final price of the derived products is, as a matter of course, minimal. This way, the extractivist operates only at the beginning stage of the formation of the chain, in its "upstream", and is rewarded solely for that participation. They do not benefit from nor have any control over the remuneration of the various productive players who act in its "downstream". This structure of distinct remunerations paid to distinct actors [as well as the] price formation of the intermediary and final products are not altered by the existence of "extractivist territories".

Furthermore, the authors cite Hirschman (1958) to emphasize that extractivist economies practically do not establish any backward linkages, in addition to establishing few forward linkages with the industrial, commercial, and services sectors.

Therefore, the RESEXes need to aggressively seek forward linkages, with the extractivists no longer being mere collectors and suppliers of coagulated latex, but taking part, as partners, in the activities of transport, primary processing, industrial transformation, marketing, etc..

It is fundamental to understand that "there should be a healthy commercial realism to protect the [extractivist] reserves from being shaken by cycles of low and high income or becoming stagnated in a tangle of indirect or direct subsidies.

The RESEXes made advances in this issue with the creation of the Central Cooperative of Extractivist Commerce of the State of Acre (COOPERACRE) ${ }^{8}$ in 2011. The Cooperative effectively represents the local associations and co-ops of the region. It regulates the prices practiced between the offer and the supply of extractivist products, especially Brazil nuts and natural coagulated rubber, with the transport and primary processing of the products. This role that Cooperacre plays is fundamental to understand the change in the price formation process of extractivist products.

First, we must highlight that the organization of the extractivists and the creation of the RESEXes altered the pattern of the traditional productive chains of non-timber forest products (NTFP), made up of the following market agents: employer, extractor, intermediary, and wholesaler. ${ }^{9}$ The RESEXes and the creation of associations and productors' cooperatives reduced the number of agents involved and the complexity of the chains, markedly in the production of native products, with the extinction of the employers, intermediaries, and wholesalers, the only remaining market actors being the extractivists, productors' cooperatives, and central cooperatives. In the case of the Brazil nut productive chain, the intermediaries remain, hindering the regulation of this market in the region.

The economic literature helps us understand the importance of the price formation ${ }^{10}$ of the NTFP being centered the RESEXes and Cooperacre: in the traditional pattern, the market is of the flex-price type, in which equilibrium is established by the market interplay between supply and demand and the prices are formed through the intermediary traders - who have been historically dominant - which is a market type considered to be in extinction (Costa, Deos, \& Brito, 2001; Ghosh, 1986).

But with Cooperacre operating in the productive chain of products like native rubber, the market becomes fix-price, for these products are organized and managed, and their prices are defined by costs and markup, and stocks are what regulates the interplay between the supply and demand of these products (Costa et al., 2001; Ghosh, 1986).

\footnotetext{
${ }^{7}$ Cf Silva (2016) e Drummond and De Souza (2016)

${ }^{8}$ For more information see https://www.cooperacre.com/

${ }^{9}$ Cf. Drummond and Souza (2016)

${ }^{10}$ Cf. Ghosh (1986, p. 122) "not all prices are determined in the same manner. While some prices, at least in the short term, are determined by demand (flex-price), some other prices are based on the cost of production and a markup (fix-price).
} 
Therefore, Cooperacre's organization and management of the products of the native rubber and Brazil nut productive chains in the Acre region are fundamental to strengthen the productive activities of the RESEXes. They are not, however, enough to ensure the maintenance and economic viability of extractivist families because these products compete in the traditional commodities market - especially native rubber, which competes with plantation and synthetic rubber - leading to lower prices. This is a trait of the price formation of agricultural products due to the gains of scale, productivity, and innovation.

According to Drummond and De Souza (2016, p. 34), the environmental attributes of a product are often the ones which receive the least remuneration, even when they are part of technologically sophisticated goods, thus requiring compensatory arrangements to provide "extra" remuneration for environmentally correct products.

Remuneration for environmental services is at the core of Payment for Environmental Services (PES) mechanisms, which are considered economic instruments of transaction (provision and consideration), aiming to maintain environmental services (Mamed \& Dallabrida, 2016) ${ }^{11}$. According to the authors, payments for environmental services can encompass a wide variety of mechanisms ${ }^{12}$, have as their object various elements of the environment, and have the possibility of being implemented vis-a-vis various social actors, therefore having multiple possible applications (p. 136).

These mechanisms can be important for the payment and recompensation of the RESEX extractivists, stimulating conservation of the forests and contributing to the social retribution of these populations via a more equitable income distribution (Raimundo C. G. Maciel, Reydon, Costa, \& Sales, 2014).

According to Maciel (2007, p. 26), a mechanism that can capture the cash flows of the positive externalities of the RESEXes is the environmental certification, which consists of an added price - stemming from the certification of socioenvironmental efficiency through the application of a Green Seal - considered a premium awarded by consumers willing to pay more for sustainable products. ${ }^{13}$

The environmental certification represents, at the last instance, a pro-environment image, that is, an intangible attribute or asset that has become a competitive differential for many companies around the world - be it in added prices in the trading of products with such attributes, the maintenance of market shares, or even the access to market niches. ${ }^{14}$

That pro-environment image is crystallized into the RESEXes, which are the combination of two unique intangible assets: the extractivist and the forest. Therefore, that image is inherent to non-timber forest products and is an important source of competitive advantages in the market. According to Maciel (2007, p. 51), the RESEX "is officially the first forest environmental certification of the region, in addition to being a relevant competitive differential for products coming from those areas."

This difference is essential to obtaining competitive advantages in the market, for according to Squeff (2019), the environmental certificate also has limitations, especially due to the multiple options of "green seals" found in the market. ${ }^{15}$ This makes it practically impossible for a product to obtain a wide variety of certifications due to the high costs involved in the implantation and maintenance of each system, leading to a comparative disadvantage.

A study done by Maciel (2007) examined the environmental certification of the Brazil nuts sold by the extractivists of the Chico Mendes RESEX. The results indicated access to specific market niches in Europe according to certifications

\footnotetext{
${ }^{11}$ See also Tavares et al. (2020)

12 Some examples, as per Young and Baker (2015) apud Mamed and Dallabrida (2016, p. 135): tax instruments, environmental compensation, enterprises in Conservation Units, billing for water consumption, royalties for natural resources and industrial services; forest servitude, carbon credits, and environmental certification.

13 See also Squeff (2019).

${ }^{14}$ For a theoretical discussion of the environmental certification, see Maciel (2007).

15 According to Maciel (2007), there are four relevant kinds of certifications: 1) of the producer's own organization (self-declaration); 2) from an association of organizations from the same industry; 3) frequently from independent organizations; 4) governmental.
} 
received in 2004 - Fair trade/FLO ${ }^{16}$ seals, organic seal (IBD) ${ }^{17}$ - and the RESEX's own seal, in addition to earning added or premium prices for the products sold.

However, after 2006, the FLO and IBD seals were de-accredited due to management issues in the local cooperatives, such as the Agroextractivist Cooperative of Brasiléia (CAPEB), related to financial problems, misapplication of resources, external mismanagement, etc. (Souza, 2010). From 2010 on, Cooperacre focused the trade of Brazil nuts on the national market, and to that end it reacquired the organic product seal, now from ECOCERT ${ }^{18}$ (Brose, 2016).

In addition to the matters of comparative disadvantages to the implementation and maintenance of acquired seals especially due to dependence on external funding, as is the case for the RESEXes - it may be more relevant to investigate how the forward linkages are established with the industrial, commercial, and services sectors, as well as their relationships with the environmental certifications, especially for products that compete in the commodities market such as native rubber.

According to Van Noordwijk and Leimona (2018, p. 2), voluntary agreements are being reached, via flexible and selfregulating arrangements, between productors, corporate firms, industrial associations, certification agencies (usually nonprofit), and governments in order to uphold the legitimacy of seals. "As part of the voluntary arrangements, eco-certification has been introduced to secure ecological and social-responsibility qualities into agricultural and forestry commodities at the point of production and subsequent trade of these commodities." 19

Still according to Van Noordwijk and Leimona (2018), there are at least three main ways to operationalize concept of payment for ecosystem services (PES):

1. Commoditization, using market mechanisms of price formation as a way to link supply to demand;

2. Compensation, imposing restrictions on land users for a common good, but compensating them for the foregone (legal) benefits ('opportunity costs');

3. Co-investment, combining resources (land, labour, capital, knowledge, rights) to move towards a more desirable configuration.

The most common entry paradigm is co-investment, verified in Southwestern Asia and Africa, but these modalities may be combined. We highlight that eco certification offers a new perspective on commoditization:

"aligning ES standards with existing commodities to increase ecosystem conditions and functions as a basis of future ES. Certification is thus a mirror image of commoditization of ES. It makes use of existing value chains and their organization, but adds to that an opportunity for end-of-chain consumers to take responsibility for what takes place at the farm" (Van Noordwijk \& Leimona, 2018).

Our study fits into this context, relating the price formation of the natural rubber productive chain in Acre and the valuation of environmental services to the environmental certification originating from the partnership between the extractivists from the Chico Mendes RESEX and the sustainable footwear company Veja Shoes.

All Veja Shoes sneakers have rubber soles made from native rubber extracted by extractivists in the Amazon. The partnership with the extractivists from the Chico RESEX began, in 2006, with a demand for a type of native rubber called Liquid Smoking Sheet (FDL - Folha de Defumação Líquida in Portuguese), named after a process that pre-processes the rubber before it even leaves the forest, adding more value to the product.

Under the aegis of the global Fair Trade movement, Veja Shoes' business model is to pay the productors more than the conventional market prices, in particular for the native rubber from Amazon extractivists and the organic cotton from the Brazilian semi-arid region.

\footnotetext{
${ }^{16}$ Fairtrade Labeling Organizations International, see: https://www.fairtrade.net/

${ }^{17}$ Biodynamic Institute, see: https://www.ibd.com.br/

${ }^{18}$ See: https://www.ecocert.com/

${ }^{19}$ Highlight added by us.
} 
The acceptance of Veja's sustainable sneakers in the international market has grown enormously. According to Lo (2018), the company's sales skyrocketed in recent years, with an annual growth of 50\% since 2015. In 2017, the company sold 550,000 pairs of shoes, generating 21 million US Dollars in revenue. In 2018, Veja supplied shoes to 1,800 retailers in 45 countries; currently, it sells in more than 60 countries.

This growth made a decisive impact on the extractivists' rubber supply: the production scale of FDL was insufficient for the growing demand of the company. ${ }^{20}$ The option presented was to buy another type of rubber from the region that could guarantee the desired quality and commercial scale: the Pressed Virgin Cernambi (CVP), ${ }^{21}$ produced by the extractivists, but processed into the form of Brazilian Dark Granulate $(\mathrm{GEB})^{22}$ by Cooperacre, which was charged with the organization and administration of the product's supply.

Thus, we can note an effective forward linkage connecting the productors to Veja Shoes. In 2019, the company started developing a program of payment for socio-environmental services (PSES) ${ }^{23}$ to consolidate its partnership with the extractivists, allocating an 'extra' remuneration over the market prices paid for the CVP, mediated by Cooperacre, with the goal of collectively building an ideal value.

In addition, a project was created to strengthen the productive chain of sustainable rubber in Acre with various goals, among them: implementing a new model of deals between Veja and the productors for the PSES; developing a forest insetting ${ }^{24}$ model for Veja; consolidating the company's monitoring system to enable the company to monitor the tappers' use of the land and implement the PSES; conducting a socio-economic evaluation of the families of the Chico Mendes RESEX; and evaluating the price formation of the rubber productive chain in Acre and the role of the PSES.

This work deals specifically with evaluating the role of the PSES in the price formation and economic viability of native rubber, and in the social reproduction of the extractivist families from the Chico RESEX. We aim to help with the decision-making of the extractivists and the company and with the consolidation and maintenance of a fair or idea PSES that fulfills the needs of an effectively sustainable development in the region.

\section{Methodology}

This study is inserted into the project titled "Diagnóstico dos Impactos Socioeconômicos da Cadeia de Fornecimento de Borracha Nativa à V Fair Trade por Famílias de Seringueiros na Reserva Extrativista Chico Mendes", since 2019, developed by the project Análise Socioeconômica de Sistemas Básicos da Produção Familiar Rural no Estado do Acre $(\mathrm{ASPF})^{25}$, captained by the Center for Applied Juridical and Social Sciences (CCJSA) of the Federal University of Acre (UFAC).

We followed the most adequate methodology for collecting primary and secondary data from the Acrean market agents of the aforementioned chain via specific questionnaires during individual interviews in order to extract the quantitative and qualitative data in the study region. This research is characterized as applied to a case study with qualitative and quantitative approaches, adopting the field research procedure (Köche, 2011; Pereira, Shitsuka, Parreira, \& Shitsuka, 2018).

\footnotetext{
${ }^{20}$ In 2018, the company bought 81 metric tons of native rubber from 303 families across 8 different communities.

${ }^{21}$ Cernambi Virgem Prensado in Portugese. Cernambi is the name for rubber that is naturally coagulated from the trees, tapped into bowls, buckets, basins, or gourds.

22 Granulado Escuro Brasileiro in Portuguese. Standardized by ABNT NBR 16120:2012.

${ }^{23}$ From 2018 to 2019 , Veja increased its PSES in $175 \%$.

24 "Insetting means evaluating, reducing and offsetting the climate and environmental footprint of a company by developing impactful socioenvironmental projects within its value chain, and using them to build a sustainable society." See more: https://www.purprojet.com/presentation-what-is-insetting/

${ }^{25}$ Translations: "Diagnosis of the Socio-Economic Impacts of the Native Rubber Supply Chain to V Fair Trade by Tapper Families in the Chico Mendes Extractivist Reserve" and Socioeconomic Analysis of Basic Systems of Rural Family Production in the State of Acre, respectively.
} 
The data collection and analysis methodology was developed based on the ASPF project, in which the evaluation is done via productivity and socio-economic indicators. The methodology of ASP was developed specifically for analyzing rural family production, particularly in the Amazon, and has been in development for the last 24 years.

The development of these studies generated an immense database on rural family production in the state. This data is available to researchers, government organs, non-governmental organizations, the academic community, and others. This wealth of information has enabled many monographs, dissertations, theses, as well as various publications, which are available for download on: http://aspf.wordpress.com/.

\subsection{Area of Study}

The object of study of this work are the market agents of the native rubber production chain in the state of Acre, particularly the agents linked to the Chico Mendes RESEX.

According to IBGE (2021), Acre is a state in the Northern region of Brazil. It borders the states of Amazonas and Rondônia and the countries Peru and Bolivia. Its extension is $164,123.737 \mathrm{~km}^{2}$ and it contains 22 cities, with Rio Branco as its capital. The population of the state as of 2019 was estimated at 881,935 inhabitants, and its population density, at 4.47 people per square kilometer. The state's Human Development Index (HDI) in 2010 was 0.663. The monthly household income per capita of its inhabitants was 890 Brazilian Real in 2019. Figure 2 shows a map with the political-administrative division of Acre.

Figure 2. Political-administrative division of Acre.

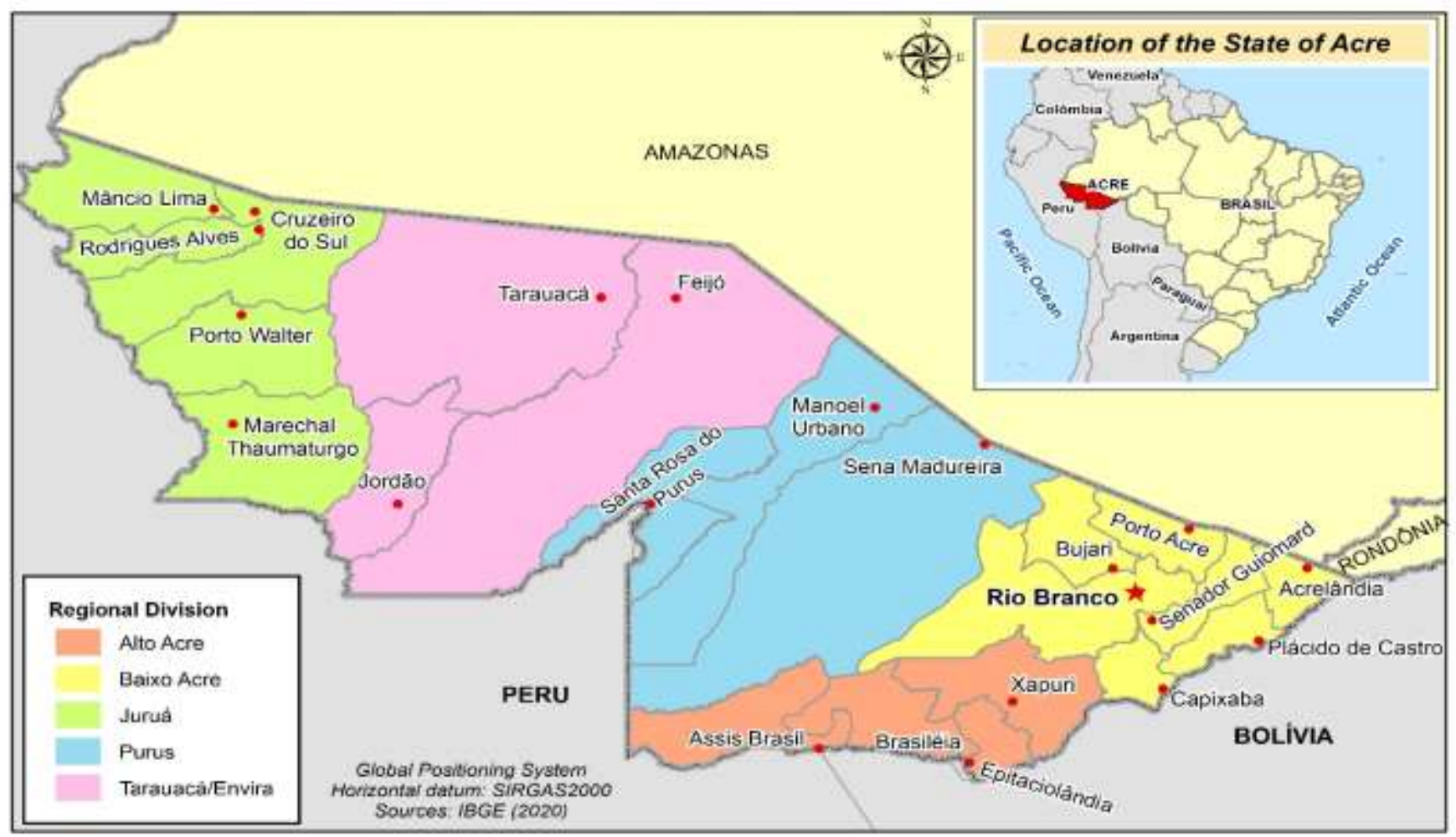

Source: IBGE (2021).

The "Chico Mendes” Extractivist Reserve (RESEX) - Creation Decree No 99,144, of March 12, 1990 - approximate area of 970,570 hectare (ha), managed by IBAMA/CNPT, was granted for sustainable use to tappers and encompasses parts of the cities of Rio Branco, Xapuri, Epitaciolândia, Brasiléia, Assis Brasil, Sena Madureira, and Capixaba, in the State of Acre, Brazil (MACIEL, 2003, p. 53). Currently, there are 2,000 production units, termed "colocações" (placements), in it. Figure 3 
shows the location of the Chico Mendes RESEX.

Figure 3. Location of the Chico Mendes RESEX, Acre, Brazil.

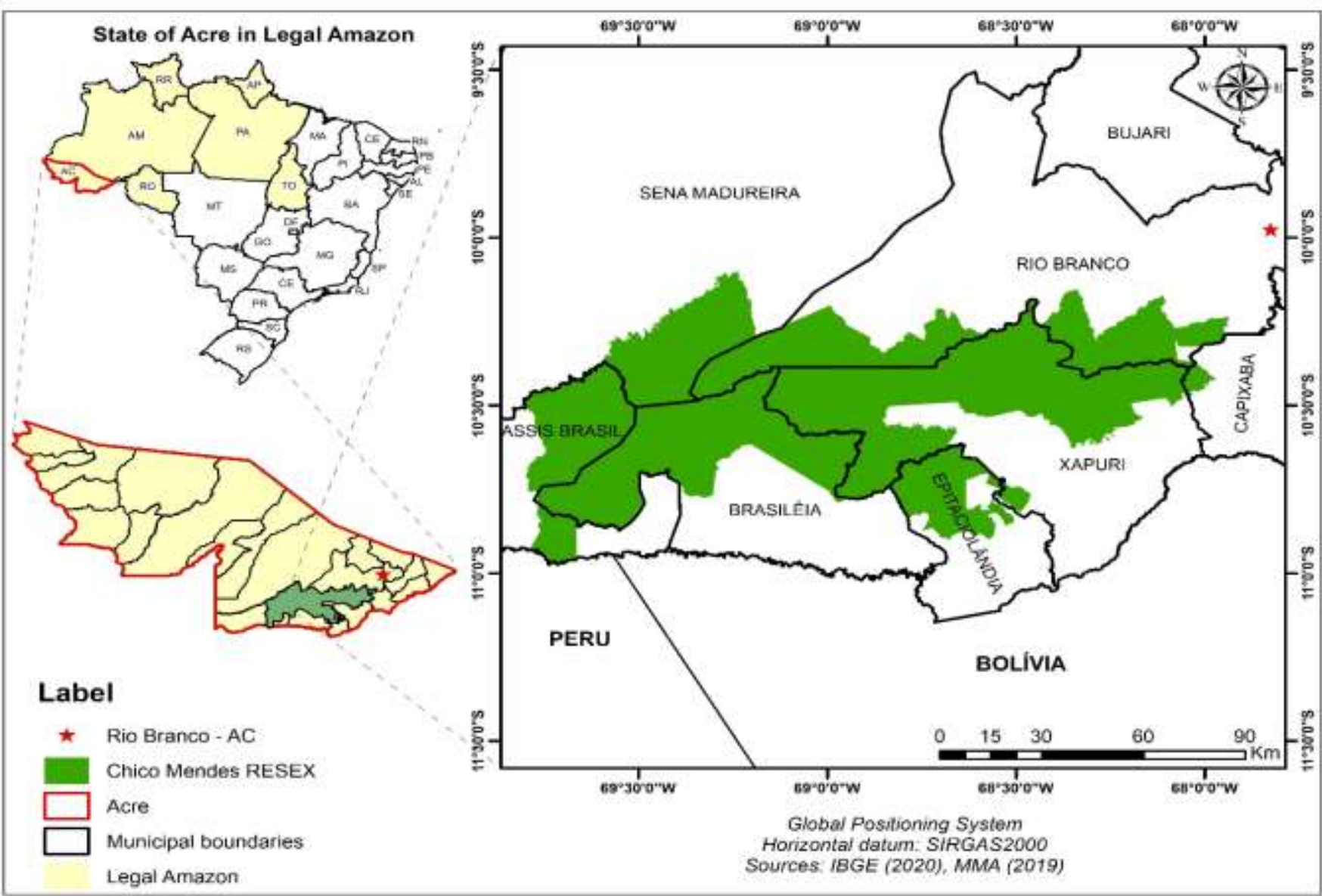

Source: Maciel (2003).

\subsection{Operation Plan}

As per Table 1 (below), we interviewed 5 market agents in the state of Acre. The interviews were based on the application of a standardized questionnaire, in which we sought to identify and classify the market agents in order to understand in greater detail the role of each agent.

Table 1. Interviewed market agents from the Acrean native rubber productive chain, 2019.

\begin{tabular}{|c|c|}
\hline Market Agents & Quantity \\
\hline Veja Fair Trade & 01 \\
\hline Producer Cooperatives & 03 \\
\hline Central Cooperative & 01 \\
\hline TOTAL & $\mathbf{0 5}$ \\
\hline
\end{tabular}

Source: Authors.

The market agents are characterized as follows:

- Producer Associations and Cooperatives: non-government entities founded by the extractivists to organize and sell the production;

- Central Cooperative (Cooperacre): Unites, in the form of an association, the extractivist associations and cooperatives 
of the state of Acre in order to organize and administer the commercialization of their products;

- Veja Fair Trade: French sustainable shoes company. Uses agro-ecological cotton from the Brazilian Semi-arid, natural rubber from the Amazon, and leather from Rio Grande do Sul. Bears the name of VERT in Brazil.

The interviews were conducted in the period of December 2019, in informal conversations with open questions, in which we tried to better know and understand the functioning of the market relationships - that is, the conditions, practices, and specificities of the commercialization among them.

\subsection{Economic Assessment Indicators}

According to Padilha Júnior (2006), the trade margin (M) corresponds to the expenses charged to customers for the execution of some negotiation function on the part of the intermediaries of the trade system. The trade margin also refers to the difference between prices at the various levels of the trade system, adjusted to the lower market level, which is always charged to the final consumer. Therefore, the trade margin must reflect the trade costs and the relative production of profit or loss of the intermediaries.

$$
\mathrm{M} \equiv C+L
$$

Where:

$$
\begin{aligned}
& M=\text { Margin; } \\
& \mathrm{C}=\text { Cost; } \\
& \mathrm{L}=\text { Profit or loss of the intermediaries. }
\end{aligned}
$$

To Junqueira and Canto (1971) apud Barros (1987) Junqueira and Canto (1971) apud Barros (1987), the margin is given by the difference between the price at which an intermediary (or group of intermediaries) sells an unit of product, and the price that intermediary pays for the quantity they need to buy in order to sell that unit.

The analysis of gross margins, as said by Padilha Júnior (2006), does not consider the losses and breakages of agricultural products along the trade system, only the price variations in an absolute or relative form. A representation of a simplified trade system can be seen in Figure 4.

Figure 1. Simplified representation of a trade chain.

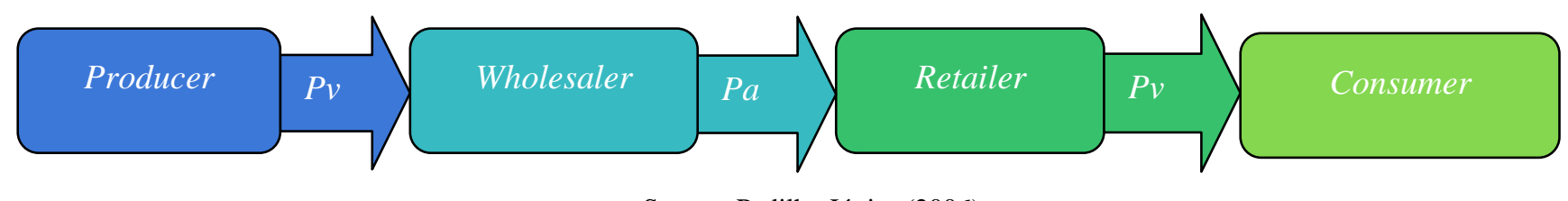

Source: Padilha Júnior (2006).

In which:

$P p=$ price in the rural property sphere, that is, price received by the producer;

$P a=$ price in the wholesale sphere, that is, price received by the wholesaler;

$P v=$ price in the retail sphere, that is, price paid by the consumer.

In addition, the presence of intermediaries in the trade directly affects the calculation of the margin, which reflects in a segmentation of the margin at each level of the trade system, as will be discussed following: 


\subsubsection{Total Margin (MT)}

The Total Margin (MT) seeks to estimate the consumer's expenses stemming from the entire trade process. The calculation of the Total Margin consists of the difference between the retail price $(P v)$ of a given product and the payment received by the producer, in the rural property sphere, for the equivalent amount of product $(P p)$. In absolute terms,

$$
M T=P v-P p
$$

The Relative Total Margin $\left(M T^{\prime}\right)$ is expressed as proportion of the retail price, that is,

$$
M T^{\prime}=[(P v-P p) / P p] .100
$$

According to Barros (1987, p. 39), the concept of trade markup is frequently used as an alternative to the margin.

\subsubsection{Trade Markup (Mk)}

Markup (Mk), according to Padilha Júnior (2006), is the difference between the sales price and the acquisition (or cost) price, that is, it shows how much price each intermediary in the trade system added to the product before passing it on to the next intermediary at the various levels of the system. In absolute terms, markup is equal to the trade margin.

In relative terms, however, markup shows the percentile increase between the sales and cost prices relative to the cost price, or between the sales price and the cost of production relative to the cost of production.

In this way,

$M k=[(P v-P c) / P c] .100$

in which:

$M k=$ Markup

$P v=$ Sales price in the market

$P c=$ Acquisition price in the market

\subsubsection{Effective Appropriation (AEi)}

According to Inhetvin (1998) and Dür (2004), the Effective Appropriation (AEi) consists of the total gross profit effectively appropriated by each type of intermediary. In this way, Effective Appropriation can be calculated from the gross profit margin multiplied by the proportional participation of each type of intermediary in the total value of the acquired product, represented by the following expression:

$$
A E_{\mathrm{i}}=M k \cdot P C_{\mathrm{i}} / P c
$$

In which,

$A E i=$ Effective Appropriation

$M k=$ Markup

$P C i=$ Proportional participation of each type of intermediary on the price

$P c=$ Acquisition price in the market

\section{Results and Discussions}

The market agents trade with each other throughout the year, and the payment method is up front. However, the market prices of the CVP also receive two subsidies: a state one, implemented by the Chico Mendes Law, since 199926, and a federal one, implemented by the National Supplying Company (CONAB) according to the Policy of Assurance of Minimum

\footnotetext{
${ }^{26}$ State Law $\mathrm{n}^{\circ} 1.277 / 99$, of the State of Acre, which pays native rubber producers a subsidy for their environmental services. Cf. Maciel et al. (2014).
} 
Prices $^{27}$, which seek to increase the earnings of the extractivists. In this sense, Veja Shoes is also granting the extractivists a payment for socio-environmental services (PSES) provided during the maintenance and production of the rubber.

From an infrastructure standpoint, no agent informed any problems with storage capacity; likewise, transportation capabilities (trucks, quads, and motorcycles) were also reported to be sufficient to keep the production flowing.

All workers hired by the agents are properly regulated according to work laws and receive between one and 2.5 minimum wages per month. In productive terms, the Acrean production of latex and its derivatives was, until recently, represented basically by coagulated latex, notably Pressed Virgin Cernambi (CVP), the Liquid Smoking Sheet (FDL), and liquid latex, which is is used in the regional condom production.

Figures 5 and 6 show the behavior of the production and prices of coagulated latex (CVP) and liquid latex in the last 28 years; FDL, given its incipient scale, still lacks representation in the IBGE statistics. In Graph 1 we note the vertiginous fall in the production of CVP, despite the implementation of the Chico Mendes RESEX in 1990, evidencing the secular downward trend in rubber prices. Though the subsidies from the Chico Mendes Law, from 1999, and the federal minimum prices, since 2009 , led to a $116 \%$ appreciation in the CVP prices in the period, they were not enough to stop the decrease in rubber production. We also note that the current minimum price of CVP is $5.58 \mathrm{BRL}^{28}$, representing the average of the prices paid since 2009 , not including the state subsidy.

Figure 2. Evolution of the Production and Prices of Coagulated Latex (CVP), Acre, 1990 to 2019.

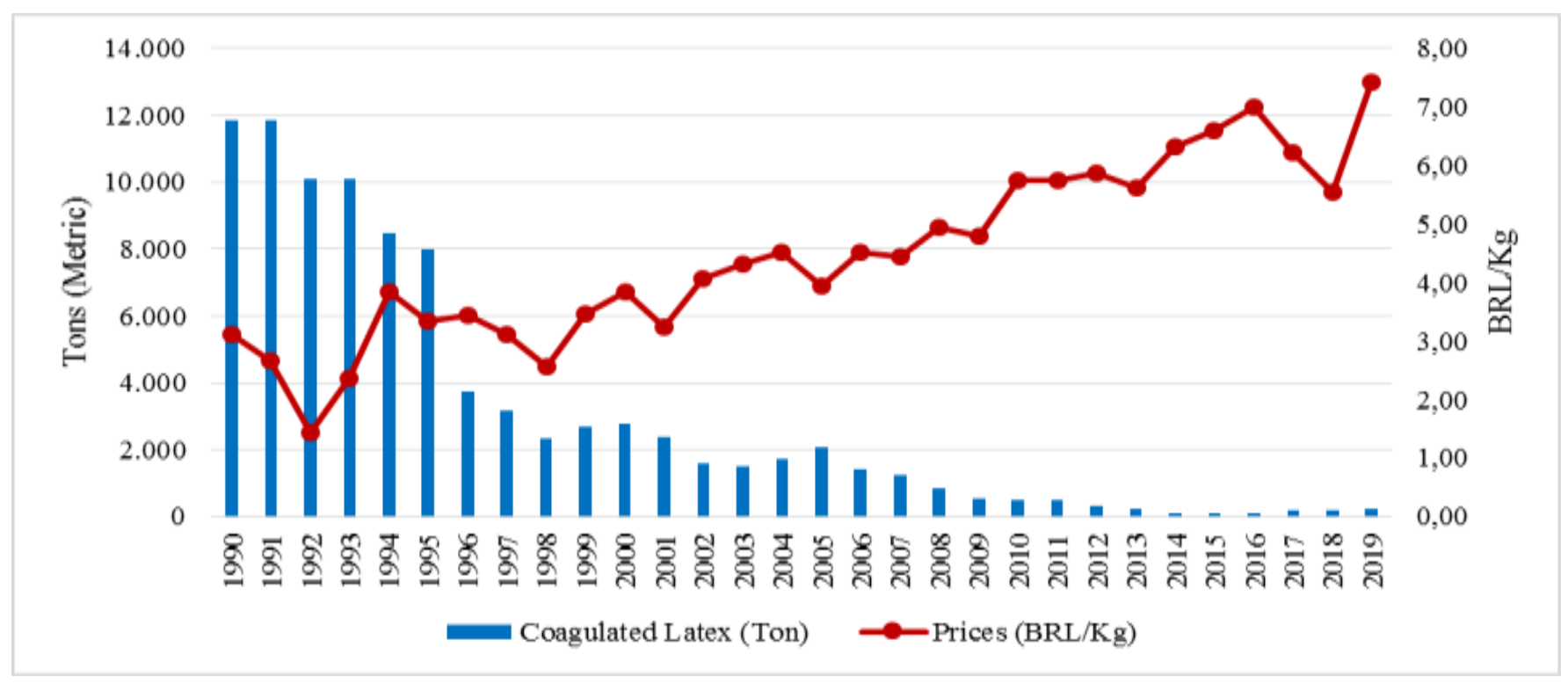

Source: IBGE (2019).

\footnotetext{
${ }^{27}$ Executed since 2009, the Policy of Assurance of Minimum Prices of Socio-biodiversity (PGPM-Bio) enables the extractivist to receive a bonus in the sale of forest products in case the trade is conducted at a price lower than the minimum price set by the government (CONAB, 2019).

${ }^{28}$ Cf. CONAB (2020).
} 
Figure 3. Evolution of the Production and Prices of Liquid Latex, Acre, 2009 to 2017.

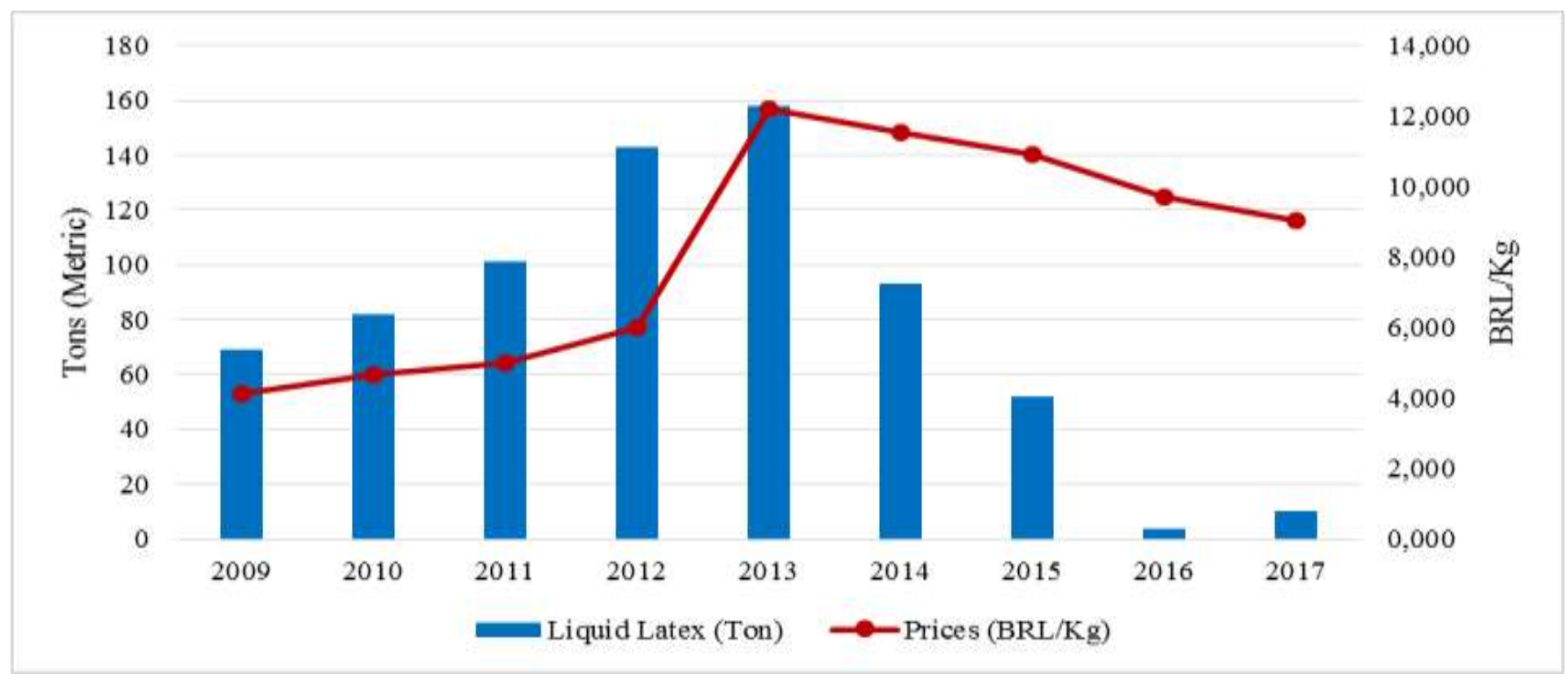

Source: IBGE (2019).

Figure 6 shows the evolution of the production and prices of liquid latex. The product appeared as an alternative to CVP, keeping in mind the implantation of a condom factory in the region, which guaranteed effective demand for the product. However, operational and financial difficulties in the factory have frustrated this promising demand, especially due to the prices practiced in the last 5 years.

FDL, initially worked by some extractivist groups in the Chico Mendes RESEX, also seemed like a promising income generation alternative for the tappers - in $2015^{29}$, its market prices were over double the prices paid for CVP, especially with regards to the supply of rubber to Vert (Veja Fair Trade) from 2006 onwards.

The growth of the market for sustainable shoes led Vert to increase its demand for its raw materials, but the FDL production could not reach a scale sufficient to fulfill that demand. Then, to maintain the sustainability of its shoes, the company began to buy and use CVP rubber processed at the GEB standard by Cooperacre, the representative of the local extractivists' associations and cooperatives in Acre. In 2018, Vert bought 115 tons of CVP, all from native tapping fields, and in 2019 it bought approximately 215 tons of native CVP, along with 120 tons of cultivated CVP (to fulfill the company's demand). Therefore, in 2019 the total quantity of CVP produced was transformed into 265 tons of GEB, processed by Cooperacre.

Therefore, the CVP production of the Acrean tapping fields wasn't enough to supply the total demand of the shoes company, there being ample space for the acquisition of rubber from native tapping fields, which is at the core of fair trade. However, as many tappers had abandoned their tapping roads, a fair amount of political articulation was necessary to organize the increase of the rubber supply in view of this recent renovation of that productive chain around distinctive markets such as the fair trade market.

Figure 7 illustrates the productive chain of rubber in Acre, showing that the processes involved in the chain are simple and easy to verify and track. 
Figure 4. Productive Chain of Rubber (Coagulated Latex - CVP), Acre, 2019.

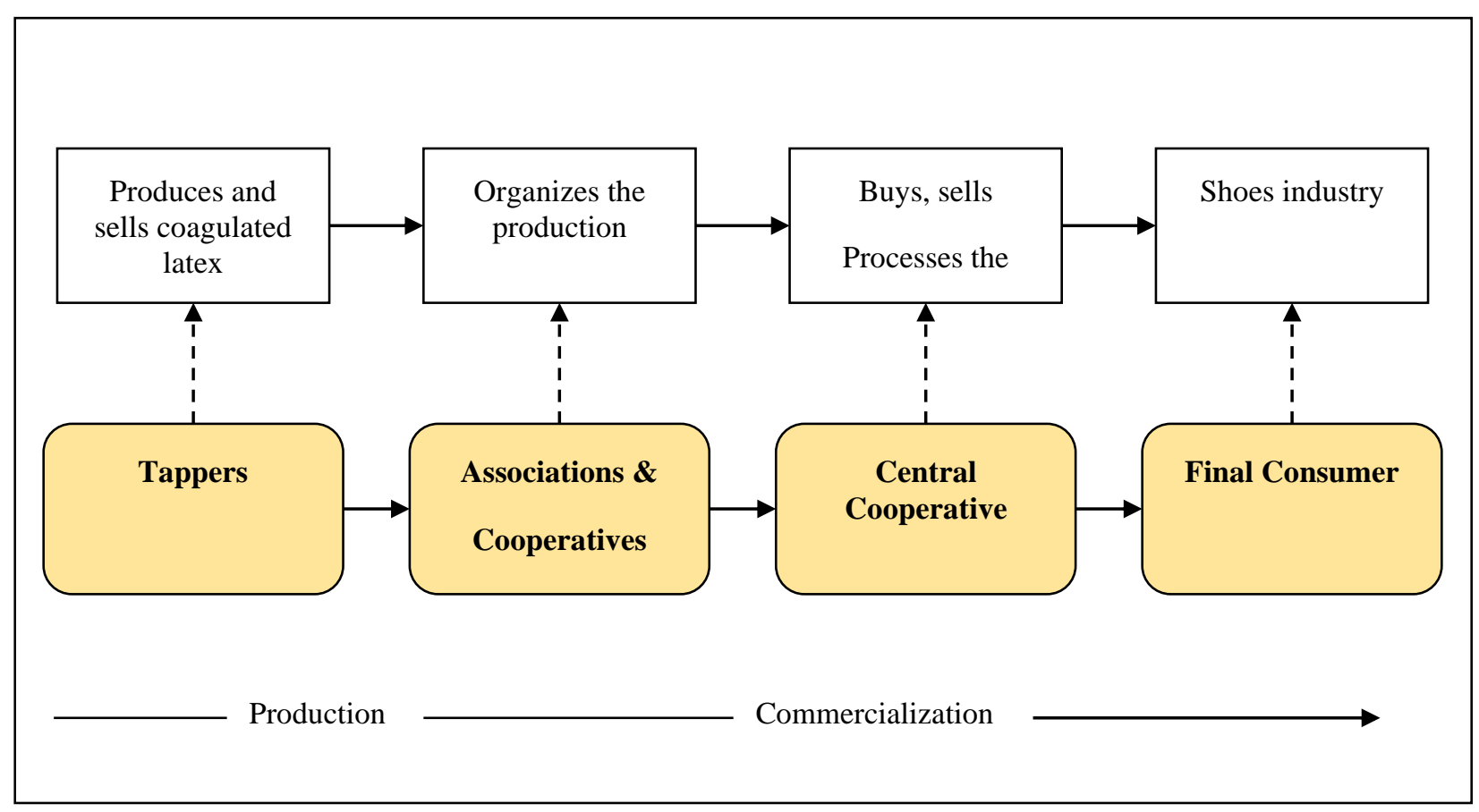

Source: Results of research.

Now, along with the visualisation of the rubber productive chain, we need to understand the workings of its price formation, from the collection and coagulation of the latex in the tappers' placements up until the final consumer, in particular the shoes industry. We highlight that normally, no balance is made between what the extractivists earn by selling their product and their production costs. This is because the price does not depend on the productors; they are receivers of prices, and must constantly adjust to the market's prices.

According to Table 2, in average terms, the tappers registered at Vert took losses in the CVP production during the 2018/2019 agricultural year, notably in the 2018 production. The high production costs of native rubber show that extractivists have to sell at least around $460 \mathrm{~kg}$ of CVP to break even; however, their median sales were $300 \mathrm{~kg}$. We also highlight that according to Maciel (2020), only approximately $33 \%$ of the tappers were able to profit from their rubber sales, because they were more efficient with lower costs or higher production levels.

Moreover, Table 2 also shows the important role of Vert in buying the rubber, for the extractivists who do not sell rubber to the company - that is, ones who live off of sporadic trade of the product - face much more difficulty in reaching economic viability. 
Table 2. Economic Indicators/Indexes of the rubber production (CVP) at the placements, by group of productors, Chico Mendes RESEX, Acre, 2018/2019 (Raimundo Cláudio Gomes Maciel, 2020).

\begin{tabular}{lccc}
\hline & Indicators & \multicolumn{2}{c|}{ Value/Index/Group } \\
\cline { 2 - 3 } & & A & B \\
\hline Economic Efficiency Index & 0.78 & 0.31 \\
Unit Cost of Production (BRL/Kg) & 15.39 & 39.05 \\
Price (BRL) & 12.00 & 12.00 \\
Amount (Kg) & 300.00 & 130.00 \\
Break-even Point of the Total Cost (Kg) & 458.45 & 688.08 \\
\hline
\end{tabular}

Obs: Median Values. A = Registered at Vert; $\mathrm{B}=$ Not registered at Vert

Source: Results of research.

Notwithstanding, the prices paid for native rubber, in 2019, according to Table 2 already contain some values that have been, over time, added to the market prices of rubber in attempts to reach a fairer price with regards to its intangible socio-environmental attributes (social equity, ecosystem services, etc.) associated to extractivist production.

According to Table 3, the prices paid for the kilogram of rubber (CVP) can reach up to $13.38 \mathrm{BRL} / \mathrm{Kg}$, if all values are effectively paid, in 2020; currently, in the trade of the product, the tappers receive the 8.00 BRL/Kg corresponding to the market price, a quality bonus - if quality is attested - and PSES paid by Vert. The state and federal subsidies are paid during the course of the bureaucratic processes of sales confirmation, on the part of the associations and cooperatives, and according to the budget availability of the government institutions.

Table 3. Price formation of rubber (CVP) according to its origin, Acre, 2019/2020.

\begin{tabular}{lc}
\hline Origin & Value (BRL) \\
\hline Market & 2.50 \\
Quality bonus & 1.00 \\
Payment for Socio-Environmental Services (PSES - Veja Fair Trade/Vert) & $4.50^{*}$ \\
State Subsidy (Chico Mendes Law) & 2.30 \\
Federal Subsidy (PGPM - CONAB) & 3.08 \\
Total & $\mathbf{1 3 . 3 8}$ \\
\hline
\end{tabular}

Note: * The current value results from a valuation of around 137\%, realized from 2018 to 2019. Source: Results of research.

Now, if the total price per kilogram of CVP can reach up to $13.38 \mathrm{BRL}$ according to table 2, why was that not the value paid in 2019? The answer relates to the financial and budget availability of the government institutions, for the state government did not transfer, in the period, the values determined by the Chico Mendes Law. Furthermore, the received values were slightly smaller because, in the value of $12.00 \mathrm{BRL}$, the PSES paid to the extractivists incorporated the value owed to the local cooperatives, which was 1.02 BRL per kilogram of CVP sold. In other words, effectively, the extractivists received approximately $11.00 \mathrm{BRL} / \mathrm{Kg}$ from the CVP trade in 2019.

Therefore, it is important to visualize the flow of production and trade of the rubber productive chain, along with the flow of prices and values earned by the market agents. This info, shown in Figure 8, helps us understand the interplay of supply and demand around CVP and how they affect the formation of the prices paid to the tappers. This understanding is essential to develop or upgrade adequate policies of payment for socio-environmental services, keeping in mind the strengthening of the rubber production in the region's tapping fields. 
Figure 5. Productive Chain of Rubber (Coagulated Latex - CVP) with the Verified Price Formation, Acre, 2020.

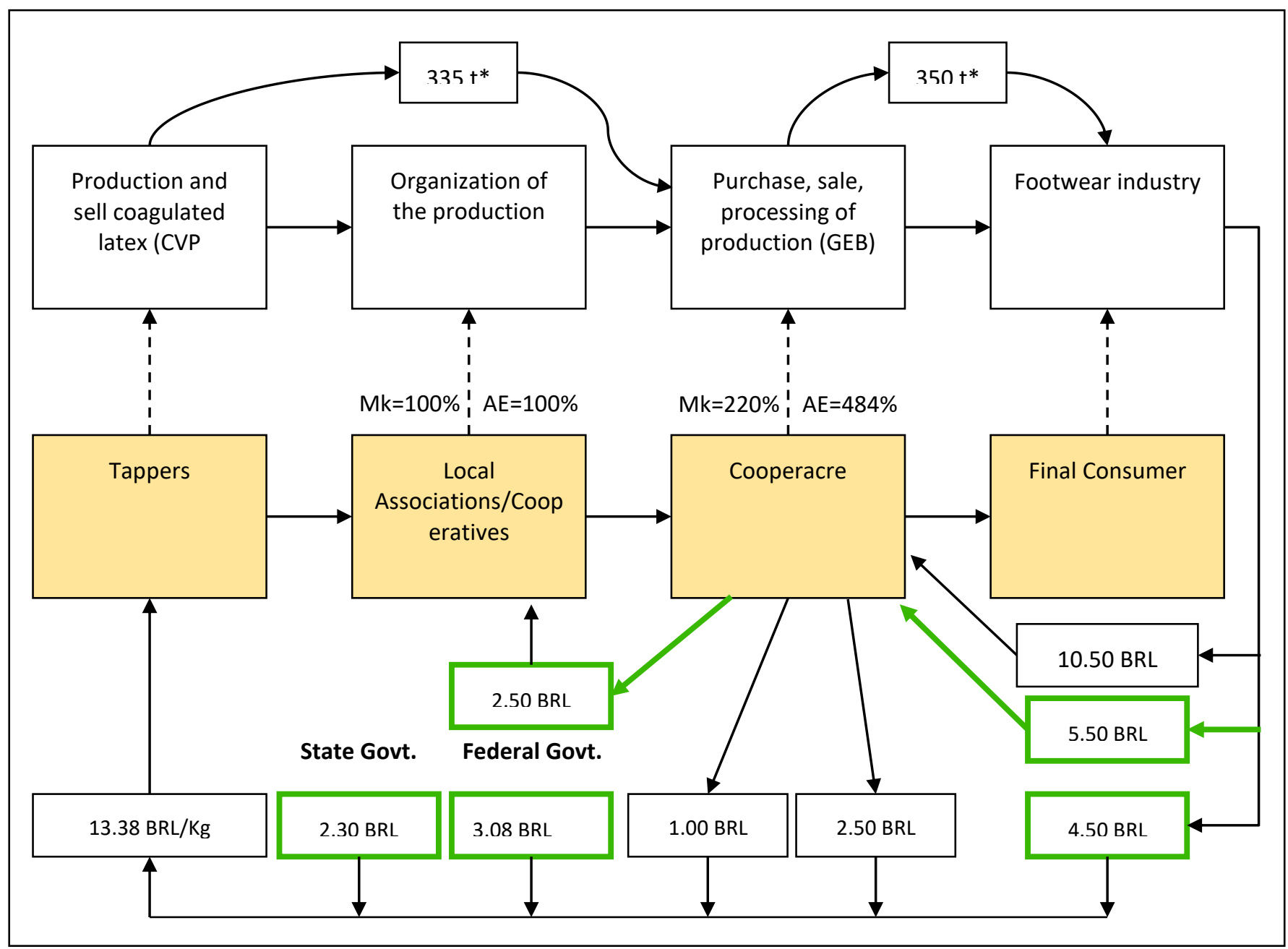

Notes: Prices and values are paid per kilogram of rubber (CVP) sold by the extractivists, or of GEB sold by Cooperacre; MK = Markup; AE $=$ Effective Appropriation; $*=$ Contract for 2020 .

Source: Results of research.

According to Figure 8, looking beyond the "door" at which the extractivists are, both the local cooperatives and Cooperacre obtain excellent margins of trade and effective appropriation during their activities in the trade of CVP and GEB, respectively. We highlight Cooperacre especially, which, in the process of accruing value to and processing the CVP, obtains a markup of $200 \%$ and an effective appropriation of $484 \%$.

For this, from 2019 to 2020, the local cooperatives had a readjustment of around 145\% in their PSES received, receiving the same price $-2.50 \mathrm{BRL}$ - per kilogram of CVP as the conventional market price of the product, justified by the high transaction costs involved in organizing the production. Cooperacre, in turn, had valuation both in its received PSES $3.00 \mathrm{BRL} / \mathrm{Kg}$ of processed CVP in 2020, a 50\% increase from the 2019 price - and in the price per kilogram of GEB of 10.50 $\mathrm{BRL} / \mathrm{Kg}$, representing an increase of $31 \%$ over the same period.

Looking back through the "door", a question may be asked: Can 13.38 BRL/Kg of CVP be considered a fairer price for the extractivists? That question can be answered according to two aspects: the productive, and that of socio-environmental services.

From the productive standpoint, the reward paid for the rubber has been very attractive to the producers, as it has motivated many tappers to go back to producing rubber or to increase their existing production. However, looking at the median costs of production, in Table 2, of $15.39 \mathrm{BRL}$, the distinguished prices received are still insufficient to elevate the 
production, as it is handled today, into economic viability.

Of course, there are some tappers who can produce at costs lower than the prices earned, but we must think about the majority of the extractivists, about how to increase their productive management. The supply of CVP to fulfill Vert's demand depends on all the collectivity of tappers, who produce in various regions and at various difficulty levels. Table 2 shows the minimum quantities necessary to make the production viable; and the native Acrean tapping fields have the possibility to meet the demand of the company given the region's productive history, as some of those fields can be said to still be "dormant".

The question is how to increase production levels in an organized manner, offering quality products and lower costs. The answer may not be so simple because it depends on an evaluation of the availability and size of the tapping fields - as well as the conditions and number of tapping roads - that are being partitioned among the inheritors of the families, the conditions of the family workforce, the capitalization of the families, the access to basic needs and materials, the degree of organization of each community, etc.

Furthermore, it also depends on the size of Vert's unfulfilled demand and of its projected evolution over time; for 2020 , the company has already made a request for 350 ton of GEB, 265 of those being native GEB and 85 being cultivated GEB due to the difficulties in acquiring the native product. We highlight that this figure of 265 ton for 2020 , which equals the company's total GEB acquisition in 2019, already presupposes an increase of 94 ton in the tappers' CVP production, which might not only motivate already registered producers to increase their offer, but encourage unregistered tappers to register as supplies for the company.

In order for the extractivists to supply, on their own, the total amount requested by the company for 2020, taking into account an average production of $460 \mathrm{~kg}$ of rubber per tapper, 1,057 tappers would be necessary; however, there are currently only 173 producers registered to supply rubber from the Chico Mendes RESEX, 113 producers from the Juruá region, and 200 new producers in the Acre region. The immediate challenge, therefore, would be to register at least 571 new producers in order to meet the demand made by Vert.

Thus, the organization/planning of the production in the native tapping fields becomes paramount; after all, the increasing demand of the shoes company reflects the great acceptance, availability, and quality of the raw materials, as well as the excellent acceptance of the sustainable shoes in the fair trade market across over 60 countries, essentially in the European market.

From the point of view of payment for socio-environmental services, the reward paid to the extractivists is further still from what would be fair: in general, the maintenance of these services depends on the reproduction and maintenance of the extractivist families in their areas and with their traditional activities. That maintenance passes through the families' constant struggle to make money in the face of their needs regarding acquiring goods, in addition to the replenishment and maintenance of assets, in the market.

According to Maciel (2020), the median line of dependency on the market among the extractivists of the Chico Mendes RESEX is 19,054.92 BRL/year or 1,587.91 BRL/month. This means that in order to generate that level of income with rubber alone, a tapper would have to produce $1,424.13 \mathrm{~kg}$, which is clearly impossible with the current methods.

According to Table 2, the median rubber production necessary for a producer to reach economic viability is around $460 \mathrm{~kg} / \mathrm{year}$. With that production and the producers' need to make money $(1,587.91 \mathrm{BRL} /$ month) solely via the rubber trade, the fair remuneration for socio-environmental services would be $41.42 \mathrm{BRL}$ per kilogram of rubber sold.

In the socioeconomic diagnosis conducted by Maciel (2020), adding up all productive activities, the gross median income earned by a family in the Chico Mendes RESEX in the period of 2018,2019 was 823.17 BRL/month, meaning a little over half the market dependency line of these families. It's also important to note that approximately $42 \%$ of that income was earned via cattle production, activity that is clearly unsustainable from an environmental standpoint. 
The rubber, with distinctive remuneration, contributed with around $24 \%$ of the total income. The Brazil nut, another traditional activity that has commercial market and scale, and which once generated a distinguished income, contributed only $8 \%$ in the analyzed period.

According to Maciel (2020), these results from the cattle and Brazil nuts may be considered atypical or specific to that economic cycle given the movement in these markets in the recent period. Furthermore, according to historic surveys in the Chico Mendes RESEX, the extractive activities, especially rubber - with its distinguished prices - and Brazil nuts, may correspond to at least half of the gross income generated, being additionally enhanced by PSES and eventually guaranteeing the reproduction of the extractivists.

Considering the current productive activities in the composition of the region's income, the value of the PSES that would be enough to maintain the families should be around 25 BRL per kilogram of rubber sold.

But without the adequate or fair payment for socio-environmental services, the families will end up seeking other, non-extractivist productive activities in order to make money, including unsustainable activities, given their market dependency - even if it is partial due to their ability to produce goods for their own consumption.

This discussion is crucial in the current moment, in which the extractivist communities - as well as their leaders and representatives - have an important partnership with a company that holds sustainability as one of its core precepts and, accordingly, rewards the producers (both directly and indirectly) for their socio-environmental services.

In this process, there have been considerable advances in effective forward linkages, connecting the producers to the company and seeking to develop mechanism to strengthen the productive chain of native rubber. Other advances have been in the carbon insetting strategy, monitoring deforestation, organizing and managing the production, availability of the socioeconomic results, and, of course, adequate and continuous planning to reach a fair remuneration for the socioenvironmental services in the region.

\section{Conclusion}

The RESEXes appear as a unique model of sustainable development for the region, fruit of the union between the environmentalist movement and the tappers' movement, seeking ecological prudence, social justice, and economic viability.

The RESEX guarantee ecologic prudence by maintaining the extractivist activities, such as rubber and nuts, which allows for the maintenance of the forest ecosystem services in the region. They also guarantee social justice via a form of land reform which grants access to the land and to means of production and subsistence. However, there are still problems with the economic viability of extractivist products, mainly due to markets failing to capture/value, in their prices, the environmental attributes of these areas, such as the case of the environmental services.

The Payments for Environmental Services arose specifically to address these market failures and adequately reward the producers of sustainable goods such as the products of vegetal extractivism.

Some PSES attempts have already been conducted with the products from the RESEXes, but they failed because they were specific implementations, dissociated from the forward linkages between the producers and the end consumers.

This study sought to analyze the price formation in the productive chain of native rubber and how it is affected by the remuneration for socio-environmental services paid to the producers by a sustainable footwear company that has formed a partnership with the extractivist communities of the region.

From a productive point of view, the valuation - not only by the company, but also by the state and federal governments - of the socio-environmental services of the RESEXes may enable the production of native rubber to reach economic viability.

From the standpoint of socio-environmental services, which are tied to the reproduction and maintenance of the 
extractivist families, the valuation realized is still insufficient to fulfill the extractivists' market dependency.

The partnership between the extractivists and the company has advanced considerably with regards to effective forward linkages, seeking to develop mechanisms to strengthen the native rubber productive chain, carbon insetting strategy, monitoring of deforestation, organization and management of the production, evaluation of the socioeconomic results, and, of course, adequate and continuous planning to reach a fair reward for the socio-environmental services of the region.

Based on the results, some evaluations can be made with the unfolding of other researches, adopting more robust quantitative approaches, especially econometric methods. Assessments are proposed in order to verify the impacts of environmental certification on deforestation at RESEX Chico Mendes, accompanied by assessments of deforestation levels before and after VERT Shoes' activities.

\section{Acknowledgments}

Study prepared based on the project titled "Diagnóstico dos Impactos Socioeconômicos da Cadeia de Fornecimento de Borracha Nativa à V Fair Trade por Famílias de Seringueiros na Reserva Extrativista Chico Mendes" ("Diagnostic of the Socioeconomic Impacts of the Native Rubber Supply Chain to V Fair Trade by Rubber Tapper Families in the Chico Mendes Extractive Reserve"), captained by Veja Fair Trade and financed by Partnerships for Forests.

This work was carried out with the support of the Coordination for the Improvement of Higher Education Personnel (CAPES) - Brazil - Financing Code 001.

\section{References}

Almeida, M. W. B. de. (2004). Direitos à Floresta e Ambientalismo: Seringueiros e Suas Lutas. Revista Brasileira de Ciências Sociais, 19(55), 33-53. https://www.scielo.br/pdf/rbcsoc/v19n55/a03v1955.pdf

Barbosa de Almeida, M. W., Allegretti, M. H., \& Postigo, A. (2018). O legado de Chico Mendes: êxitos e entraves das Reservas Extrativistas. Desenvolvimento e Meio Ambiente, 48(Edição especial: 30 Anos do Legado de Chico Mendes), 25-55. https://doi.org/10.5380/dma.v48i0.60499

Barros, G. S. de C. (1987). Economia da comercialização agrícola (Vol. 1). FEALQ.

Brose, M. E. (2016). Cadeias produtivas sustentáveis no desenvolvimento territorial: a castanha na Bolívia e no Acre, Brasil. Interações (Campo Grande), 17(1). https://doi.org/10.20435/1518-70122016108

CMMAD. (1991). Nosso Futuro Comum (2nd ed.). Editora da Fundação Getúlio Vargas.

CONAB - Companhia Nacional de Abastecimento. (2019). Política de Garantia de Preços Mínimos para Produtos da Sociobiodiversidade (2nd ed.). https://www.conab.gov.br/images/chamadas/politicas_programas/cartilha-pgpm-bio 2019_digital.pdf

CONAB - Companhia Nacional de Abastecimento. (2020). Portal de Informações Agropecuárias: Preços Mínimos - Borracha Natural (cernambi). Companhia Nacional de Abastecimento website: https://portaldeinformacoes.conab.gov.br/precos-minimos/precos minimos-dashboard

Costa, F. N. da, Deos, S. S. de, \& Brito, J. V. de. (2001). Meta Inflacionária, Juros e Preços no Varejo Brasileiro. Revista de Economia Política, 21(4 (84)), 93-111. https://centrodeeconomiapolitica.org.br/rep/index.php/journal/article/view/997

Costanza, R., de Groot, R., Braat, L., Kubiszewski, I., Fioramonti, L., Sutton, P., \& Grasso, M. (2017). Twenty years of ecosystem services: How far have we come and how far do we still need to go? Ecosystem Services, 28(Part A). https://doi.org/10.1016/j.ecoser.2017.09.008

Drummond, J. A., \& De Souza, C. (2016). A extração da flora e fauna nativas na Amazônia brasileira - uma segunda apreciação. Desenvolvimento e Meio Ambiente, 36(2), 9-53. https://doi.org/10.5380/dma.v36i0.42715

Dürr, J. (2004). Manual Metodologia de Pesquisa Empírica para Construção de Cadeias Produtivas e Contas Sociais de Base Agrária (Vol. 1). Belém: NAEA.

Ghosh, D. (1986). Fix Price-Flex Price in Development Economics. Australian Economic Papers, 25(46), $122-127$.

Goeschl, T., \& Igliori, D. C. (2006). Property Rights for Biodiversity Conservation and Development: Extractive Reserves in the Brazilian Amazon. Development and Change, 37(2). https://doi.org/10.1111/j.0012-155X.2006.00484.x

Hall, A. (2000). Environment and Development in Brazilian Amazonia: From Protectionism to Productive Conservation. In A. HALL (Ed.), Amazonia at the Crossroads: The challenge of sustainable development (1st ed., Vol. 1, pp. 99-114). London: IILAS.

Hirschman, A. O. (1958). The Strategy of Economic Development (Vol. 10). https://doi.org/10.2307/1235188 
IBGE - Instituto Brasileiro de Geografia e Estatística. (2019). Produção da Extração Vegetal e da Silvicultura. Sistema IBGE de Recuperação Automática website: https://sidra.ibge.gov.br/pesquisa/pevs/tabelas/brasil/2019

IBGE - Instituto Brasileiro de Geografia e Estatística. (2021). Cidades e Estados. Portal Cidades website: https://www.ibge.gov.br/cidades-e-estados/ac.html

Inhetvin, T. (1998). Agricultores familiares, agentes mercantis e a comercialização de produtos agrícolas: o caso de Capitão Poço. Papers Do NAEA, 100, 102-undefined.

Kitamura, P. C. (1995). Políticas ambientais para a Amazônia: uma avaliação crítica. In J. M. M. da Costa (Ed.), Amazônia: desenvolvimento econômico, desenvolvimento sustentável e sustentabilidade de recursos naturais. NUMA.

Köche, J. C. (2011). Fundamentos de Metodologia Científica. http://www.adm.ufrpe.br/sites/ww4.deinfo.ufrpe.br/fil es/Fundamentos_de_Metodolo gia_Científica.pdf

Lo, A. (2018). Would you pay more for sustainable sneakers? CNN Business website: https://edition.cnn.com/2018/10/28/business/veja sneakers/index.html

Maciel, R. C. G., Reydon, B. P., Costa, J. A. da, \& Sales, G. de O. (2014). Paying for Environmental Services. Journal of Environmental Protection, 05(05). https://doi.org/10.4236/jep.2014.55045

Maciel, R. C. G. (2003). Ilhas de alta produtividade: inovação essencial para a manutenção dos seringueiros nas reservas extrativistas. Universidade Estadual de Campinas, Campinas.

Maciel, R. C. G. (2007). Certificação ambiental: uma estratégia para conservação da floresta amazônica. Universidade Estadual de Campinas, Campinas.

Maciel, R. C. G. (2020). Diagnóstico Socioeconômico da Produção Familiar Rural na Reserva Extrativista (Resex) Chico Mendes - Período 2018/2019. Rio Branco.

Maciel, R. C. G., Cavalcanti, F. C. da S., de Souza, E. F., de Oliveira, O. F., \& Cavalcante Filho, P. G. (2018). The "Chico Mendes" extractive reserve and land governance in the Amazon: Some lessons from the two last decades. Journal of Environmental Management, 223(1). https://doi.org/10.1016/j.jenvman.2018.06.064

Maciel, R. C. G., Oliveira, O. F. de, Cavalcante Filho, P. G., Ribeiro, L. N., Silva, G. S. A. L. da, Araújo, W. D. S., \& Silva, Í. H. B. da. (2019). Distribution of Income and Poverty in the Chico Mendes Extrative Reserve (Resex). Journal of Agricultural Studies, 7(2), 138-159. https://doi.org/10.5296/jas.v7i4.15310

Mamed, D. D. O., \& Dallabrida, V. R. (2016). Instrumentos econômicos de proteção ambiental e desenvolvimento territorial: abordagem teórica e prospecções para o Planalto Norte Catarinense. DRd - Desenvolvimento Regional Em Debate, 6(2). https://doi.org/10.24302/drd.v6i2.1217

Millennium Ecosystem Assessment. (2005). Ecosystems and Human Well-being: Synthesis. In Island Press. https://www.millenniumassessment.org/docu ments/document.356.aspx.pdf

Padilha Júnior, J. B. (2006). Comercialização de Produtos Agrícolas. https://materiais.tripod.com/sitebuildercontent/sitebuilderfiles/apostila2006sc.pdf

Pereira, A. S., Shitsuka, D. M., Parreira, F. J., \& Shitsuka, R. (2018). Metodologia da Pesquisa Científica (Vol. 1). https://repositorio.ufsm.br/bitstream/hand le/1/15824/Lic_Computacao_Metodologia-Pesquisa-Cientifica.pdf?sequence=1

Silva, A. G., Da Silva, F. C., \& Yamada, T. (2019). Reprodução social de populações tradicionais e pecuária na Reserva Extrativista Chico Mendes: reflexões a partir dos projetos de vida de jovens extrativistas. Desenvolvimento e Meio Ambiente, 52, 235-260. https://doi.org/10.5380/dma.v52i0.65423

Silva, R. R. (2016). Extrativismo e Desenvolvimento na Amazônia: Discussões a partir da formação de preços da borracha (Hevea Brasiliensis) no Acre. Universidade Federal do Acre, Rio Branco.

Souza, G. E. de A. B. (2010). Reserva Extrativista Chico Mendes - AC: os desafios da gestão (com)partilhada. Universidade Federal de Viçosa.

Squeff, T. de A. F. R. C. (2019). O papel da certificação ambiental na consecução do desenvolvimento e consumo sustentável. Revista Da Faculdade de Direito Da UFG, 43, 1-22. https://doi.org/10.5216/rfd.v43.57757

Tavares, E. G., Silva, T. G. A., \& Machado, V. G. (2020). Mercados da biodiversidade: análise dos programas de pagamento por serviços ambientais. In L. Scur, J. R. Gimenez, \& C. F. Burgel (Eds.), Biodiversidade, recursos hídricos e direito ambiental (Vol. 1). Educs.

Van Noordwijk, M., \& Leimona, B. (2018). Eco-certification and the commoditization of ecosystem services. In S. Namirembe, B. Leimona, M. Van Noordwijk, \& P. Minang (Eds.), Co-investment in ecosystem services: global lessons from payment and incentive schemes (Vol. 1). World Agroforestry Centre (ICRAF).

Wanderley, M. de N. B. (2014). O campesinato brasileiro: uma história de resistência. Revista de Economia e Sociologia Rural, 52(suppl 1). https://doi.org/10.1590/S0103-20032014000600002

Young, C. E. F., \& Medeiros, R. (2018). Quanto vale o verde: a importância econômica das unidades de conservação brasileiras (Vol. 1). Conservação Internacional. 